\title{
SPAULDING, Amy E. The art of storytelling: telling truths through telling stories. Lanham, MY: Scarecrow Press. 2011.
}

\section{vi, 210 pages. ISBN 978-0-8108-7776-4 (hardback) £30.35, ISBN 978-08108- 7777-1 (ebook) £22.76.}

Lets face it - we all tell stories, at work to protect a colleague, socially to present a situation in a more favourable or humorous light, and also in a formal sense to our children or grandchildren and other junior relatives. For me it goes further than that, to the way we construct our own life narrative which consists of a series of stories we change and alter to fit in with our current world view or aspirations. So when I had the chance to review a book on storytelling I was intrigued.

This is an excellent book on the art and ethics of storytelling, my only disappointment was it was not long enough. Spaulding has a conversational writing style which is very pleasantly readable and also allows her to effortlessly digress into interesting asides, Also she writes from a position of considerable moral and ethical authority, for which I have a great respect. I simply wanted her to write for longer so I could keep reading.

Spaulding is an expert in the art of storytelling having served her apprenticeship with New York Public Library under the guidance of Augusta Baker. The current volume is in response to the upsurge in interest, within and beyond the library profession, by an individual who honestly admits she is far happier speaking than writing. Spaulding is very clear that storyteller needs to be aware of the ethical and moral dimension of their art before they get out there telling stories. So Spaulding tells us about storytelling and tells us about herself as storyteller, innocently demonstrating how it should be done.

The book has 16 short chapters in three main sections: Telling truth, telling stories; How to become a story teller; Why bother learning and telling stories - and Farwell which includes the final chapter on the values of the story teller and the value of stories.

The opening section is slightly disconcerting as the author assumes (not unreasonably) that you wish to become a story teller and congratulates the reader on the choice they have made. The second part (How to become a story teller) is a very practical stage by stage apprenticeship moving from how to learn stories to selecting stories, building a performance repertoire, performance, working with an audience. She even closes by exploring the financial side of storytelling.

The third section takes us into interesting areas which the would be story teller needs to know about, yet would probably not notice until they had been telling stories for some time. The difference between storytelling and story crafting (I discovered in my coaching work I engage in story crafting - as I ruthlessly adapt the story to fit the group or individual I am working with) The chapter on the ethics and psychology of storytelling contains powerful personal examples of the requirement for the storyteller to allow the story to speak for itself. Spaulding also deals with the role of the story teller in times of uncertainty, where the story and the teller can provide hope and inspiration for their audience. 
The appendices contain a series of useful resources for further exploration and development. A storiography listing stories with a brief description of the content (p. 139 - 177), a list of story collections $(179-188)$ and a webliography (p.189 193 ) covering both story sources and sites for story tellers. There is also a very useful and wide ranging bibliography (p. 195 - 202) covering everything from Joseph Campbell to Dorothy Sarnoff.

If you consider yourself a storyteller, or wish to enter this fraternity, then Spaulding's book is something you have to read. Having gained your initial orientation you can they pursue the bibliography to widen your knowledge base while you get out their delivering to hone your performance skills. The book will also be useful to researchers engaged in qualitative research as it will help them understand the nature of the stories they are being told. For those in management positions it provides an opportunity for a quick read that might enable them to understand the ethical (or otherwise) nature of their organisational narratives, and consequently become more honest in their approach?

This book is about storytelling however due to Spaulding's gift with words and evident wisdom it is also a useful guide to ethical qualities needed to serve your community truthfully.

\section{References}

Baker, A. and Greene, E. (1977) Storytelling: art and technique. New York : Bowker, 1977

Spaulding, A. (2004) The wisdom of storytelling in an information age. Lanham, MD: Scarecrow Press.

Keith V. Trickey

Programme Manager

Liverpool Business School and Sherrington Sanders

K.V.Trickey@ljmu.ac.uc

\section{Open access and copyright}

Library and Information Research is an open access journal. A freely available copy of this paper may be downloaded from the journal's website:

http://www.cilipjournals.org.uk/lir

Copyright and associated moral rights in works published in Library and Information Research are retained by the author(s) but this paper may be used freely, with proper attribution, in educational and other non-commercial settings. 